\title{
Hubungan Negatif Antara Tingkat Inflasi dengan Tingkat Kemiskinan di Wilayah Perdesaan Provinsi Lampung
}

\author{
ANDRAWINA SUSANTO \\ Badan Pusat Statistik Provinsi Lampung \\ email: andrawina@bps.go.id
}

\begin{abstract}
ABSTRAK
Menurut teori, tingkat inflasi akan berpengaruh positif pada angka kemiskinan. Namun pada beberapa penelitian, hal itu bisa saja bertentangan. Itulah sebabnya maka penting untuk menguji hubungan kedua variabel tersebut di beberapa lokasi di Indonesia. Penelitian ini mengkaji pengaruh inflasi terhadap angka kemiskinan di wilayah perdesaan di Provinsi Lampung. Metode yang digunakan adalah statistika analitik menggunakan teknik regresi linear sederhana dengan menggunakan data sekunder hasil survei sosial ekonomi dan survei harga perdesaan dari BPS Provinsi Lampung tahun 2012 - 2017. Hasil analisis telah memenuhi uji asumsi klasik sehingga model regresi linear sederhana dapat digunakan dalam memprediksi variabel kemiskinan di perdesaan. Temuan awal penelitian ini menyimpulkan bahwa inflasi perdesaan berpengaruh negatif terhadap tingkat kemiskinan perdesaan di Provinsi Lampung sebesar 0,061. Artinya semakin tinggi pertumbuhan inflasi perdesaan, maka semakin rendah tingkat kemiskinannya. Hal itu berbanding terbalik dengan landasan teori yang mungkin disebabkan oleh adanya fenomena sosial tertentu atau karena inflasi merupakan determinan dari makro ekonomi, sehingga bisa saja tidak berpengaruh langsung pada tingkat kemiskinan. Hal ini bukan saja terjadi pada kajian ini, tetapi juga pada beberapa kajian sebelumnya. Pada akhirnya, hal ini membutuhkan penelitian lanjutan yang lebih komprehensif untuk wilayah-wilayah lain di Indonesia, untuk dapat lebih memahami hubungan antara dua variabel tersebut.
\end{abstract}

Kata kunci: Inflasi Perdesaan, Tingkat Kemiskinan, Pertumbuhan, Regresi Linear Sederhana

\begin{abstract}
In theory, the inflation rate will have a positive impact on poverty rates. But in some studies, that could have been contradictory. That is why it is important to discuss the relationship between the two variables in several locations in Indonesia. This study examines the effect of inflation on poverty in rural areas in Lampung province. The method used is analytical statistics using simple linear regression techniques using secondary data from the results of the socio-economic survey and rural price survey from BPS Lampung province in 2012 - 2017. The results of the analysis have fulfilled the classical assumption test so that a simple linear regression model can be used in predicting rural poverty variables. The results of this preliminary study concluded that rural inflation negatively affected rural poverty rates in Lampung province by 0,061. This means that the higher the growth of rural inflation, the lower the level of poverty. This is inversely proportional to the theoretical basis which may be caused by the existence of certain social phenomena or because inflation is a determinant of the macro economy, so that it may not have a direct effect on the level of poverty. This not only happened in this study, but also in several previous studies. In the end, this requires further comprehensive research for other regions in Indonesia, in order to better understand the relationship between these two variables.
\end{abstract}

Keywords: rural inflation, level of poverty, growth, simple linear regression.

\section{PENDAHULUAN}

Secara teori peningkatan inflasi berpengaruh positif terhadap tingkat kemiskinan. Dalam Shaleh K, Sugiartiningsih (2017), hubungan antara inflasi dengan kemiskinan suatu negara adalah searah. Kenaikan inflasi akan tercermin dari kenaikan harga barang dan jasa yang 


\section{Andrawina Susanto}

tersedia dan dibutuhkan masyarakat sehingga berefek menurunkan daya beli. Secara global kejadian ini akan menurunkan kesejahteraan secara riil atau dapat pula dikatakan menaikkan kemiskinan. Namun penelitian yang mengkaji lebih spesifik mengenai pengaruh inflasi di perdesaan terhadap tingkat kemiskinan di perdesaan masih belum banyak dikaji.

Jumlah penduduk miskin di wilayah perdesaan dari tahun 2009 sampai dengan 2016 dapat dilihat pada gambar berikut:

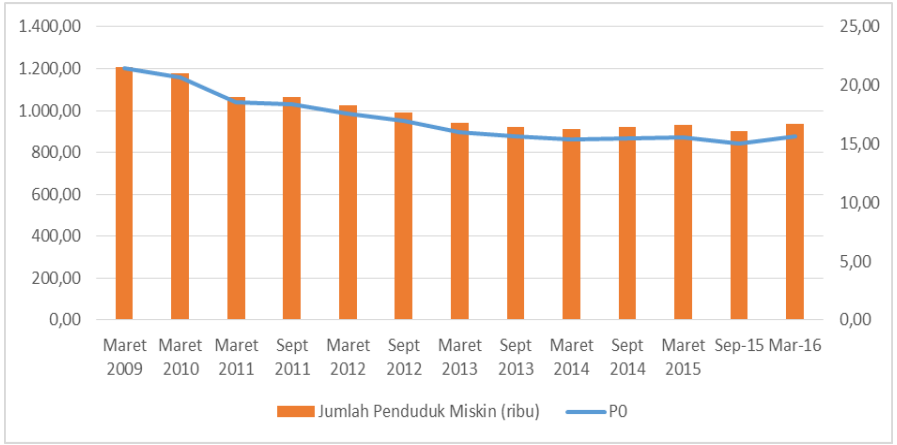

Sumber data : BPS, diolah

Gambar 1. Jumlah Penduduk Miskin di Wilayah Perdesaan dari Tahun 2009 -2016

Dari gambar 1 dapat dilihat pertumbuhan jumlah penduduk miskin dan pergerakan tingkat kemiskinan di wilayah perdesaan. Tahun 2009 merupakan pertumbuhan penduduk miskin di perdesaan tertinggi yaitu 1,2 juta jiwa bergerak berfluktuatif cenderung menurun hingga tahun 2016 menjadi 936 ribu jiwa. Dalam pertumbuhannya, jumlah penduduk miskin di perdesaan mencapai titik terendah sebesar 902 jiwa pada tahun 2015. Hal tersebut sejalan dengan pergerakan tingkat kemiskinan $\left(\mathrm{P}_{0}\right)$ yang menurun. Tingkat kemiskinan perdesaan berada di titik tertinggi pada tahun 2009 yaitu 21,49 dan bergerak melambat hingga tahun 2016 pada titik 15,69. Selama pertumbuhannya tingkat kemiskinan di perdesaan mencapai titik terendah 15,05 pada tahun 2015. Penelitian ini dilakukan untuk melihat pengaruh tingkat inflasi terhadap tingkat kemiskinan dipedesaan dengan menggunakan teknik regresi linear sederhana.

\section{METODE PENELITIAN}

\section{Kemiskinan}

Kemiskinan adalah suatu keadaan dimana seseorang tidak sanggup memelihara dirinya sendiri sesuai dengan taraf kehidupan kelompok dan juga tidak mampu memanfaatkan tenaga mental, maupun fisiknya dalam kelompok tersebut (Soekanto, S 2012).

Nugroho, Iwan 2012 mengemukakan kemiskinan merupakan suatu kondisi absolut atau relatif di suatu wilayah di mana seseorang atau kelompok masyarakat tidak mampu mencukupi kebutuhan dasarnya sesuai tata nilai atau norma yang berlaku. Jika dipandang dari aspek ekonomi, kemiskinan menunjuk pada gap antara lemahnya purchasing power dan keinginan dalam memenuhi kebutuhan dasar.

Kemiskinan adalah ketidakmampuan dari sisi ekonomi untuk memenuhi kebutuhan dasar makanan dan bukan makanan yang diukur dari sisi pengeluaran. Jadi penduduk miskin adalah penduduk yang memiliki rata-rata pengeluaran perkapita perbulan dibawah Garis Kemiskinan (GK) yaitu kebutuhan konsumsi makanan setara 2100 kilo kalori perhari. Dalam mengukur tingkat kemiskinan ada tiga indikator penting yang digunakan yaitu Head Count Index (HCI-Po), adalah persentase penduduk yang berada dibawah GK, Indeks Kedalaman Kemiskinan (Poverty Gap Index- $\mathrm{P}_{1}$ ) (BPS, 2018).

\section{Jenis-jenis kemiskinan}

Kemiskinan dapat dibedakan menjadi kemiskinan absolut dan kemiskinan relatif. Kemiskinan absolut memandang kemiskinan dalam suatu ukuran yang bersifat mutlak yang bermuara 
atau berwujud sebagai garis, titik, atau batas kemiskinan. Sementara kemiskinan relatif, memandang kemiskinan dalam suatu ukuran yang dipengaruhi ukuran-ukuran lain yang berhubungan dengan proporsi atau distribusi (Nugroho, Iwan 2004).

Kartasasmita, G, 1996 mendefinisikan kemiskinan merupakan masalah dalam pembangunan yang ditandai dengan pengangguran dan keterbelakangan, yang kemudian meningkat menjadi ketimpangan. Sementara itu (Todaro, M. dan Smith, S, 2003) menggambarkan kemiskinan berdasarkan aspek spasial. Secara sederhana, penduduk miskin adalah mereka yang pada umumnya bertempat tinggal di daerah perdesaan, dengan mata pencaharian pokok dibidang pertanian dan kegiatan-kegiatan lainnya yang erat hubungannya dengan sektor ekonomi tradisional.

\section{Indikator Tingkat Kemiskinan}

Ada tiga indikator kemiskinan yang digunakan berdasarkan pendekatan kebutuhan dasar yaitu (BPS, 2018):

- Head Count Index (HCI-Po) yang memberikan persentase penduduk miskin yang berada di bawah GK.

- Indeks Kedalaman Kemiskinan (Poverty Gap Index- $\mathrm{P}_{1}$ ) yang merupakan ukuran rata-rata kesenjangan pengeluaran masing-masing penduduk miskin terhadap GK. Semakin tinggi nilai indeks ini, semakin jauh rata-rata pengeluaran penduduk dari GK.

- Indeks Keparahan Kemiskinan (Poverty Severity Index-P2) adalah gambaran tentang penyebaran pengeluaran di antara penduduk miskin.

Persamaan (Foster, J., J. Greer, dan E. Thorbecke, 1984) :

$$
P_{\alpha}=\frac{1}{N} \sum_{i=1}^{q}\left[\frac{z-y_{i}}{z}\right]^{\alpha}
$$

$Z \quad$ = garis kemiskinan

$\mathrm{y}_{\mathrm{i}}=$ rata-rata pengeluaran per kapita sebulan yang berada di bawah garis kemiskinan

$\mathrm{q}=$ jumlah penduduk hidup di bawah garis kemiskinan

$\mathrm{N}=$ jumlah penduduk

$\mathrm{A}=0$, head count index, $\%$ penduduk miskin

$\mathrm{a} \quad=1$, poverty gap (indeks kedalaman kemiskinan), defisit penduduk miskin terhadap garis kemiskinan

$\mathrm{a}=2$, poverty severity index (indeks keparahan kemiskinan)

\section{Inflasi Perdesaan}

Inflasi perdesaan merupakan proxy yang disusun oleh Indeks Konsumsi Rumah Tangga (IKRT). IKRT berisi informasi mengenai perkembangan harga barang dan jasa yang dibayar konsumen di perdesaan (BPS, 2018). Jenis barang dan jasa tersebut dikelompokkan menjadi 7 kelompok, yaitu: bahan makanan, makanan jadi, minuman, rokok, dan tembakau, perumahan, sandang, kesehatan, pendidikan, rekreasi dan olah raga, transport dan komunikasi. Persamaan IKRT:

$I K R T_{n}=\frac{\sum_{i=1}^{n} \frac{r_{n i}}{P_{(n-1) i}} P_{(n-1) i} Q_{o i}}{\sum_{i=1}^{k} P_{o t} \cdot Q_{o i}}$

Pni = harga jenis barang $\mathrm{I}$, periode ke-n

$\mathrm{P}(\mathrm{n}-1) \mathrm{I}=$ harga jenis barang I, periode ke $(\mathrm{n}-1) \mathrm{P}(\mathrm{n}-1) \mathrm{i}$.

$\mathrm{POi}=$ nilai konsumsi jenis barang $\mathrm{I}$, periode ke- (n-1) POi.

Qoi = nilai konsumsi jenis barang I pada tahun dasar

$\mathrm{K} \quad=$ jumlah jenis barang paket komoditas Selain dari Susenas 


\section{Andrawina Susanto}

\section{Pengembangan Hipotesis}

Mengacu pada landasan teori diatas, maka dapat diturunkan hipotesis sebagai berikut :

$\mathrm{H}_{0}$ : Tidak ada pengaruh yang nyata (signifikan) variabel inflasi di perdesaan terhadap variabel kemiskinan di perdesaan

$\mathrm{H}_{1}$ : Ada pengaruh yang nyata (signifikan) terhadap variabel inflasi di perdesaan terhadap variabel kemiskinan di perdesaan

Penelitian ini menggunakan pendekatan kuantitatif. Menurut Saifuddin,A 2011, pendekatan kuantitatif adalah penelitian yang analisisnya lebih fokus pada data-data numerikal (angka) yang diolah dengan menggunakan metode statistika. Dalam penelitian ini peneliti menggunakan statistik analitik dengan teknik analisis regresi linier sederhana untuk melakukan pemodelan dan uji asumsi klasik yang diolah dengan menggunakan SPSS 18. Data yang diolah merupakan data sekunder dari hasil Survei Sosial Ekonomi Nasional (SUSENAS) dan Survei Harga Perdesaan (SHPed) tahun 2012 sampai dengan 2017. Survei tersebut adalah survei yang dilakukan oleh BPS Provinsi Lampung. Sampel dalam penelitian ini data kemiskinan di perdesaan $\left(\mathrm{P}_{0}\right)$ sebagai variabel tidak bebas $(\mathrm{Y})$ dan inflasi perdesaan (IKRT) sebagai variabel bebas $(\mathrm{X})$.

Adapun persamaan regresi dari desain penelitian tersebut adalah sebagai berikut:

$\mathrm{KMSK}=a+\beta \mathrm{IN}$

Pada persamaan di atas KMSK adalah variabel kemiskinan perdesaan $\left(\mathrm{P}_{0}\right)$ dan IN adalah variabel inflasi perdesaan (IKRT) dengan a adalah konstanta dan adalah $\beta$ koefisien. Dalam penelitian ini digunakan data IKRT yang merupakan proxy pembentuk inflasi perdesaan. Dalam penelitian selanjutnya diharapkan dapat menggunakan perubahan IKRT sebagai komponen variabel bebas.

Penelitian yang sejenis mengenai kemiskinan dan faktor yang mempengaruhinya cukup banyak. Namun untuk wilayah perdesaan belum ada yang melakukan penelitian sehingga ini menjadi hal yang menarik untuk dikaji dan diteliti.

\section{HASIL DAN PEMBAHASAN}

\section{Hasil}

- Uji Normalitas

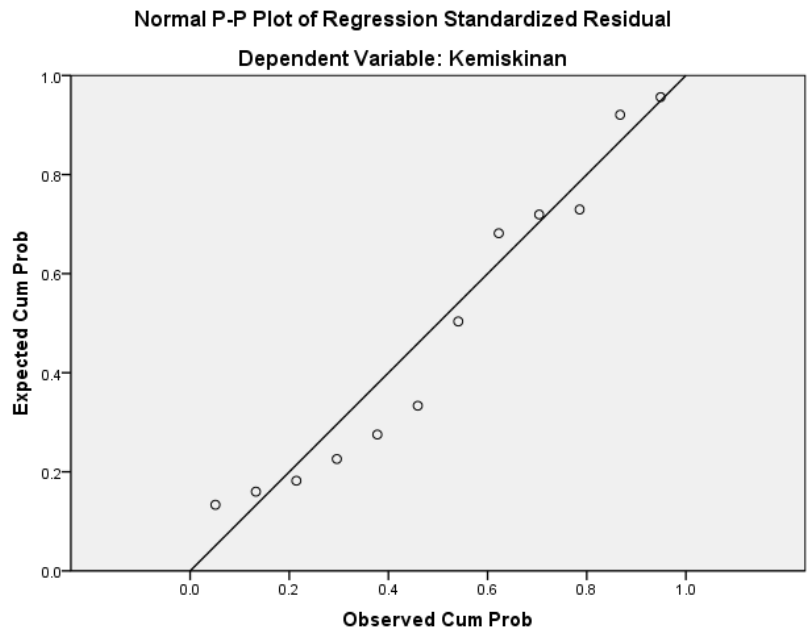

Sumber: Data Sekunder diolah SPSS versi 18.0

Gambar 2. Normal P-P Plot 
Dari hasil pengolahan dengan menggunakan SPSS versi 18.0 didapatkan gambar 2 yang memperlihatkan titik-titik mengikuti dan mendekati garis diagonalnya menunjukkan bahwa data memenuhi asumsi normalitas.

- Uji Heteroskedastisitas

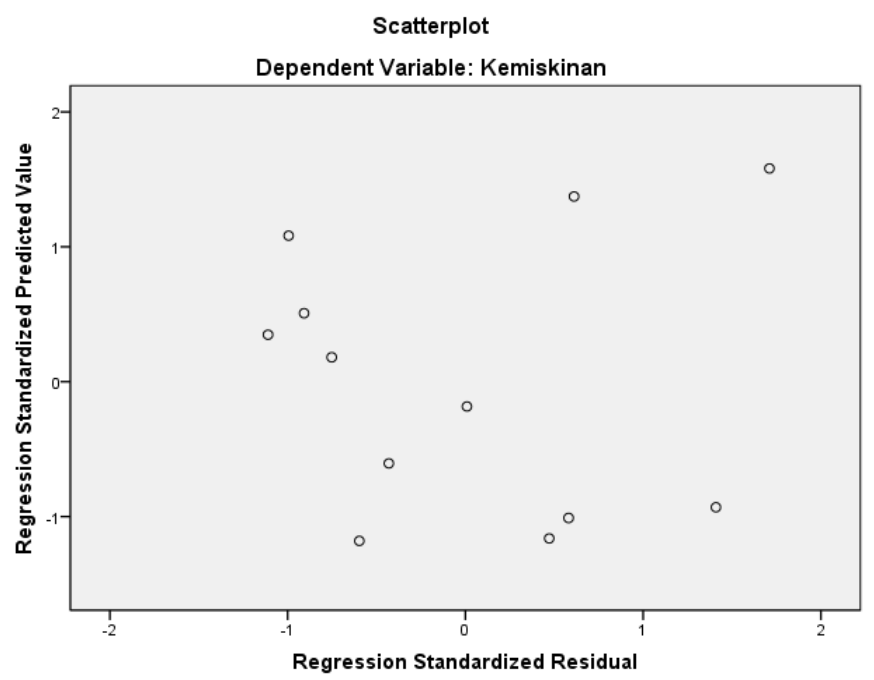

Sumber: Data Sekunder diolah SPSS versi18.0

Gambar 3. Scaterplot

Gambar 3 menunjukkan titik-titik yang menyebar dan tidak membentuk pola tertentu yang jelas. Sehingga dapat disimpulkan bahwa tidak terjadi masalah heteroskedastisitas

- Uji Parsial Persamaan Regresi

Analisis signifikansi dari nilai koefisien persamaan model regresi sederhana dilakukan dengan pengujian statistik yaitu uji t-statistik. Dari hasil pengujian t-statistik didapat variabel inflasi di perdesaan memiliki koefisen -5,002 dengan nilai signifikansi 0,001<0,05, maka $\mathrm{H}_{0}$ ditolak dan $\mathrm{H}_{1}$ diterima, yang berarti ada pengaruh yang nyata (signifikan) variabel inflasi perdesaan (IKRT) terhadap variabel kemiskinan perdesaan.

Dari hasil output program didapatkan nilai korelasi (R) yaitu sebesar 0,845 dan koefisien determinasi $\left(\mathrm{R}^{2}\right)$ sebesar 0,714, yang mengandung pengertian bahwa pengaruh variabel bebas (IKRT) terhadap variabel terikat (kemiskinan) adalah sebesar $71,40 \%$, sedangkan sisanya dipengaruhi oleh variabel yang lain.

Selain itu dari hasil output program terlihat bahwa $F$ hitung $=25,017$ dengan tingkat signifikansi 0,001 < 0,05, maka model regresi dapat dipakai untuk memprediksi variabel kemiskinan.

Perhitungan koefisien untuk persamaan regresi linear sederhana dari data tahun $2012-2017$ diperoleh hasil :

\section{KMSK $=22,699-0,061$ IN}

Pada persamaan di atas KMSK adalah variabel kemiskinan perdesaan dan IN adalah variabel inflasi perdesaan. Bila inflasi perdesaan atau IN sebesar nol maka angka kemiskinan perdesaan atau KMSK sebesar 22,699 \%. Inflasi perdesaan mempunyai hubungan negatif terhadap kemiskinan perdesaan. Disaat inflasi perdesaan naik sebesar $1 \%$ maka kemiskinan perdesaan turun sebesar 0,061\%.

\section{Pembahasan}

Gambar 4 memperlihatkan inflasi perdesaan dari tahun 2012 sampai dengan 2017 terjadi peningkatan. Tingkat inflasi perdesaan tertinggi 129,78 tahun 2017 dan terendah sebesar 98,42 tahun 2012. Tingkat inflasi tinggi selama periode yang diteliti adalah 105,88 (2013); 112,97 (2014); 120,64 (2015); 126,47 (2016). Sedangkan kemiskinan perdesaan setiap tahun 


\section{Andrawina Susanto}

terlihat menurun dari 16,95 tahun 2012 menjadi 14,56 tahun 2017. Tingkat kemiskinan perdesaan bergerak cenderung berfluktuasi menurun dengan tingkat kemiskinan perdesaan tertinggi pada tahun 2012 yaitu 16,95. Dalam pergerakannya hingga tahun 2017 mencapai titik terendahnya sebesar 14,56.

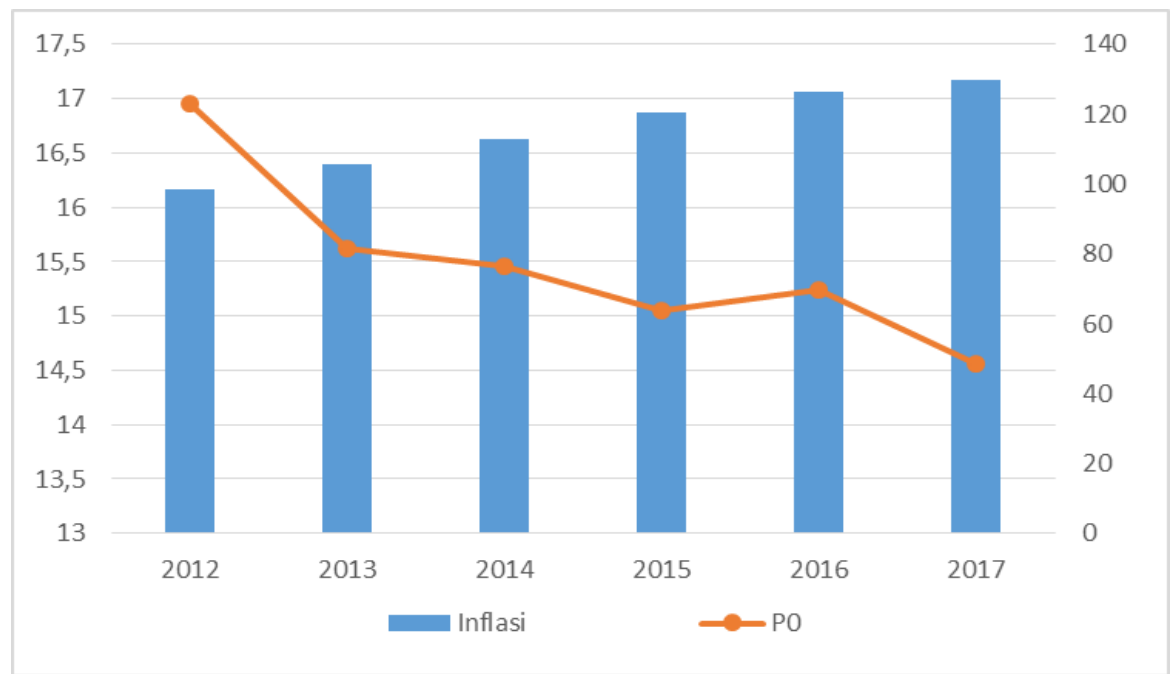

Sumber : Data sekunder diolah

Gambar 4. Hubungan antara Inflasi dan Kemiskinan di Wilayah Perdesaan

Tahun $2012-2017$

Model regresi linear sederhana yang diperoleh dapat dipakai untuk memprediksi variabel kemiskinan di perdesaan. Namun variabel bebasnya yaitu inflasi perdesaan (IKRT) mempunyai hubungan negatif terhadap varibel terikat yaitu kemiskinan di perdesaan. Semakin tinggi tingkat inflasi di perdesaan, semakin menurun angka kemiskinannya. Hal ini tidak sejalan dengan hasil penelitian sebelumnya yang menyatakan bahwa inflasi berpengaruh positif terhadap kemiskinan di Indonesia. Sehingga dalam

penelitian berikutnya perlu dikaji apakah pertumbuhan inflasi mempengaruhi tingkat kemiskinan di wilayah perdesaan dengan menggunakan variabel perubahan IKRT.

Karakteristik pola konsumsi masyarakat perdesaan yang berbeda dengan masyarakat perkotaan menjadi hal yang menarik untuk dikaji. Hal ini terkait dengan kebijakan pemerintah dalam mengendalikan harga barang yang selanjutnya dapat meningkatkan daya beli masyarakat perdesaan.

\section{KESIMPULAN}

Dari penelitian hasil pengujian secara langsung dengan teknik regresi linear sederhana menunjukkan tingkat inflasi di perdesaan berpengaruh negatif terhadap tingkat kemiskinan di perdesaan. Hal tersebut tidak sejalan dengan penelitian lainnya yang sejenis. Sehingga perlu penelitian lebih lanjut dengan menggunakan variabel perubahan IKRT. Selain itu, belum banyaknya peneliti yang mengkaji wilayah perdesaan terkait dengan kemiskinan dan faktor yang mempengaruhinya, menjadikan topik ini menarik untuk dilakukan penelitian.

\section{DAFTAR PUSTAKA}

BPS, Data dan Informasi Kemiskinan Kabupaten/Kota Tahun 2017. Jakarta : 2018.

BPS, Statistik Nilai Tukar Petani 2017. Jakarta : 2018.

Foster, J., J. Greer, dan E. Thorbecke. 1984. Notes and Comments: A Class Decomposable Poverty Measures. Econometrica, 52(3): 761-766.

Kartasasmita, G. Pembangunan Untuk Rakyat Memadukan Pertumbuhan Dan Pemetaan. Jakarta: CIDES, 1996. 
Nugroho,Iwan, Pembangunan Wilayah Perspektif Ekonomi, Sosial Dan Lingkungan. Jakarta:

LP3ES, 2004.

Saifuddin,A, Metode Penelitian.Yogyakarta : Pustaka Pelajar, 2011.

Shaleh K, Sugiartiningsih, Pengaruh Inflasi Terhadap Kemiskinan di Indonesia Periode 1998-2014 (Inflation Influence On Poverty in Indonesia Period 1998-2014), Universitas Widyatama : 2017.

Soekanto, S, Sosiologi Suatu Pengantar. Jakarta: Raja Grafindo Persada: 2012.

Todaro, M. dan Smith, S. Pembangunan Ekonomi di Dunia Ketiga. Edisi Kedelapan. Jakarta:

Erlangga, 2003. 